\title{
China's Outer Space Programme: Diplomacy of Competition or Co-operation?
}

\author{
Jayan Panthamakkada Acuthan
}

\section{OpenEdition}

1 Journals

Édition électronique

URL : http://journals.openedition.org/chinaperspectives/577

DOI : $10.4000 /$ chinaperspectives.577

ISSN : 1996-4617

Éditeur

Centre d'étude français sur la Chine contemporaine

Édition imprimée

Date de publication : 1 février 2006

ISSN : 2070-3449

Référence électronique

Jayan Panthamakkada Acuthan, « China's Outer Space Programme: Diplomacy of Competition or Cooperation? », China Perspectives [En ligne], 63 | january - february 2006, mis en ligne le 01 février 2009, consulté le 10 décembre 2020. URL : http://journals.openedition.org/chinaperspectives/577 ; DOI : https://doi.org/10.4000/chinaperspectives.577

Ce document a été généré automatiquement le 10 décembre 2020.

(C) All rights reserved 


\title{
China's Outer Space Programme: Diplomacy of Competition or Co- operation?
}

\author{
Jayan Panthamakkada Acuthan
}

1 The beginnings of the Chinese space programme can be traced back to the research and development (R\&D) on missiles modelled on foreign sources in the late 1950s reportedly with Soviet technological assistance and to a lesser extent with some knowledge of the US missile programme ${ }^{1}$. The politicians who played a critical role in this programme were Zhou Enlai, Lin Biao, and the Gang of Four ${ }^{2}$. Zhou and Lin believed that China's accomplishments in space would be translated into international prestige. The Gang of Four's interest was based on their attempt to move the focus of space operations from Beijing to Shanghai. In 1975, the developments of the communications satellites were included in the State Plan. Under Deng Xiaoping, the military space programme focused on geo-synchronous communication satellites ${ }^{3}$. These satellites combined with earth-imaging satellites were vital for command, control and intelligence. The first geo-synchronous communication satellite was launched on April 8th 1984 aboard the Long March 3 booster. In 1986, space was accorded the highest priority status in the technological programme. After a series of small and medium-size rocket launches during the 1960s, a preliminary launch of an intercontinental rocket was conducted in the early 1970s, but the first full range launch test of an intercontinental rocket only took place more than nine years later, on May $1980^{4}$.

2 The PLA's ABM programme included the construction of two anti-missile systems: the Fan Ji (counter-attack) 1 and the Fan Ji 2. A Fan Ji 3 was also designed but the Fan Ji programme reportedly did not survive the chaos of the Cultural Revolution ${ }^{5}$. PRC aerospace engineering reports from the mid-1990s also indicate that the PRC is developing anti-missile or anti-satellite systems ${ }^{6}$.

3 Research and Development in rocket technology is the responsibility of the Chinese Academy of Space Technology (CAST), while the China Academy of Launch Vehicle 
Technology (CALT) is in the charge of the development of space launchers. At present, rocketry developments come under the Ministry of Aero-Space Industry (MAI) ${ }^{7}$. China's space launchers are indigenously built ${ }^{8}$ and the first generation, designated Chang Zheng (CZ) (Long March), placed China's first satellite in space in April 1970. This made China the fifth member of the world's most exclusive international club, able to launch a satellite into the Earth's orbit. Since their early days, $\mathrm{CZ}$ rockets have considerably evolved. One variation of the CZ series is the FB-1 (WW, Feng Bao or Storm) rocket developed in Shanghai. One of its features is that it can launch more than one satellite at a time. FB-1 rockets have launched six satellites from the time they came into service to September 1988. Geostationary orbit launches are assumed by follow-on versions, the CZ-3 and the CZ-4 rockets. CZ-3 rockets were put into service in 1984 and have since performed all launches to this orbit, with the exception of the 1988 and 1990 CZ-4 launches of Chinese satellites'.

4 Most of the above rockets are launched from two launch sites operated by the China Satellite Launch and TT\&C General (CLTC), one at Jiuquan in Gansu province, the other at Xichang in Sichuan province. A third launch site, near Taiyuan in Shanxi province, does not appear in official Chinese publications as such, but was used for the launch of CZ-4 rocket in September $1988^{10}$.

5 Chinese development of satellite applications has focused on the fields of remote sensing, communications, and space physics exploration. The CAST develops most of the applications. The majority of these satellites have been recoverable remote sensing ${ }^{11}$. China entered the international satellite launch market with the launch of the Asiasat-1C in 1990, the Arabsat-1C, the Freja, and two Aussat satellites in $1992^{12}$. China is also engaged in research in areas such as high capacity communication satellites and multipurpose Earth resource satellites, large volume and long-life communication and broadcast satellites, and ground application systems for satellites ${ }^{13}$. In this context, China's space policy projects the development of all types of space application satellite systems, as well as the building of a space station, a heavy launch vehicle, and a space transportation system. Xie Mingbao, director of the China Manned Space Engineering Office, was quoted as saying that China spent "18 billion yuan (about US $\$ 2.2$ billion) on the five spacecraft of the Shenzhou (Divine Vessel) series that have been launched so far" ${ }^{14}$. Annual spending on the total Chinese space programme is difficult to ascertain. Joan Johnson-Freese, of the US Naval War College, estimates that China spends US $\$ 1.4$ billion-2.2 billion annually on space, but cautions against direct comparisons with US space spending because of currency conversions issues ${ }^{15}$. The Chinese space programme still lags behind its US counterpart in terms of experience, expertise and resources, but the Chinese regime is not sitting idle as the United States continues to be the dominant space power ${ }^{16}$. It is likely that China has acquired from the former Soviet Union the technical know-how to operate the direct ascent method of satellite negation, similar to the co-orbital method of interception. The laser weapon capability of blinding low-earth orbit satellites appears to be close to fruition. Certainly there are no technological barriers to China developing such a system.

On October 15th 2003, at 9 am local time, at Jiuquan, China has launched atop a Long March $2 \mathrm{~F}$ rocket its first-ever piloted spacecraft by a "taikonaut" ${ }^{17}$, the Shenzhou V; thus successfully propelled, after the Soviet Union and the United States, into the exclusive country club having sent a man into space ${ }^{18}$. On October 16th 2003, Lieutenant Colonel Yang Liwei, 38, stepped onto the grasslands of the Inner Mongolia 
Autonomous Region, ending his 21-hour journey as the first Chinese to travel into outer space. He orbited the earth 14 times (21 hours and 23 minutes) travelling some 600,000 $\mathrm{km}$. In mid-October 2005, astronauts Fei Junlong (40) and Nie Haisheng (41) were the focus of a over a billion pairs of eyes as they stepped aboard the Shenzhou VI spacecraft at the Jiuquan Satellite Launch Center ${ }^{19}$.

7 Space-related Intellectual Property Rights (SIPRs) is becoming increasingly important, especially with the completion of International Space Station (ISS) ${ }^{20}$. The ISS, one of the most important examples of co-operation among space-faring nations, is the most appropriate test case for reviewing the effect of the regulatory environment with respect to intellectual property rights in outer space. Can inventions made in outer space be patented on Earth? Can the use of patented inventions be protected in outer space? These questions would dominate among the experts in the years to come.

Aims and principles of China's space activities

8 The aims and principles of China's space activities are determined by their status and function in protecting China's national interests and in implementing the state's development strategy as contained in the white paper entitled "China's National Defense in 2002"21. According to the white paper, China implements a military strategy of active defence. On arms control and disarmament, the white paper acknowledges that after the end of the Cold War, a series of achievements were made in the field of international arms control, disarmament and non-proliferation. In the current situation, it is critically important to maintain the global strategic balance and stability and the legal system governing international arms control and disarmament. China has consistently advocated the complete prohibition and thorough destruction of chemical weapons, biological weapons and nuclear weapons.

9 The use of the space sector ranges from civil, commercial, military and security activities to securing space for peaceful purposes ${ }^{22}$. The principal aims of China's space activities are: to explore outer space, and learn more about the cosmos and the Earth; to utilise outer space for peaceful purposes, promote mankind's civilisation and social progress and benefit the whole of mankind; and to meet the growing demands of economic construction, national security, science and technology development and social progress, protect China's national interests and build up a comprehensive national strength.

10 Some experts do not rule out the possibility that China may also proceed with a military space station programme along the lines of that of the United States named the Orbiting Laboratory (MOL) programme of the 1970s, which was finally abandoned. China carries out its space activities is accordance with the following principles ${ }^{23}$ : - adhering to the principle of long-term, stable and sustainable development and making the development of space activities cater to and serve the state's comprehensive development strategy. The Chinese government attaches great importance to the significant role of space activities in implementing the strategy of revitalising the country with science and education and that of sustainable development, as well as in economic construction, national security, science and technology development and social progress. The development of space activities is encouraged and supported by the government as an integral part of the state's comprehensive development strategy; 
13 upholding the principle of independence, self-reliance and self-renovation and activity promoting international exchanges and co-operation. China shall rely on its own strength to tackle key problems and make breakthroughs in space technology. Due attention should be given to international co-operation and exchanges in the field of space technology, and self-renovation in space technology shall be combined organically with technology import or the principles of mutual benefit and reciprocity. selection of a limited number of targets and making breakthroughs in key areas according to the national situation and strength. China carries out its space activities for satisfying the fundamental demands of its modernisation drive. enhance the social and economic returns of space activities and pay attention to the motivation of technological progress.

16 The Chinese government develops space technology, application and science through integrated planning and rational arrangement in the aim of promoting the comprehensive and co-ordinated development of China's space activities. China's distinctive path to space development includes both military applications and international co-operation. Countries involved with Chinese programme include Russia and the former Soviet republics, the United States, Canada, United Kingdom, Germany and Brazil. An important characteristic of China's military space is that it relies heavily on its co-operation with other countries. In the United States this co-operation caused a great political dispute and led to a Congressional investigation, especially in connection with space launch market co-operation.

17 "Now, China ranks among the most advanced countries in the world is many technological fields, such as satellite recovery, multi-satellite launch with a single rocket, rockets with cryogenic fuel, strap-on rockets, launch of geo-stationary satellites and Telemetry Tracking and Command (TT\&C). Significant achievements have also gained in the development and application of remote-sensing satellites and telecommunications satellites, and in manned spacecraft testing and space microgravity experiments" ${ }^{24}$.

18 According to China's official position, outer space should be used exclusively for peaceful purposes. China is therefore opposed to any militarisation of space, including and especially space-based missile defence systems. China has made strong statements against any type of arms race, including arms race in space. In both the 1998 and 2000 white papers on national defence, China called for the creation of a multilateral mechanism to prevent an arms race in outer space.

19 China is opposed to the weaponisation of space for a number of reasons. Most importantly, Beijing opposes the use of space-based equipment is missile defence systems, such as the space-based sensors and intercept warheads in outer space potentially to be deployed is planed US missile defence systems. China is concerned that the US deployment of missile defences, especially national missile defence (NMD), will negate its strategic nuclear deterrent, potentially forcing China into an expensive arms race that it cannot currently afford. Beijing's focus on arms control in outer space is an attempt to block future deployment of missile defence by the United States.

20 In addition, as the United States rapidly improves its ability to deploy weapons systems in space, China is concerned that this pre-eminence will enable the United States to use this technology to achieve global dominance. China's defence industry has seen the difficulties in developing and absorbing new technologies and the cost of developing 
space-based sensors and weapons, Beijing worries it will be unable to match the United States for an indefinite period of time. Without a formal multilateral agreement banning the deployment of space-based weapons, the United States will have an increasing strategic advantage for the foreseeable future. Moreover, Beijing is aware of US preparation for future space warfare against China, as seen by various reports of US war games with China as "enemy". For example, in early 2001, a war game in Colorado pitted the United States against an opponent threatening a small neighbour (i.e., China threatening Taiwan), where both the two main countries facing off were relying heavily on space assets. As a result of these reports, China increasingly views itself as the target of US increased militarisation (and possible weaponisation) of space ${ }^{25}$.

China's co-operation in outer space

21 China for the United States and Europe will increasingly be a space competitor-both commercially and politically in the Asia-Pacific region. It also means that China offers a whole new range of space co-operation options. Europe is already increasing space cooperation with China. Germany participated earlier in Chinese communications satellite development. In 1994, China Aerospace Company and Germany's Deutsche Aerospace (now DASA) formed joint venture, Euraspace, to build remote-sensing communication satellites. The first was launched in July 1998. Alcatel in France has signed an agreement with the Chinese wherein Alcatel will provide the communications payload for China's new communications spacecraft. The European Space Agency (ESA) has also begun work with China on the twin spacecraft Double Star Science Mission. For the United States, the same issues that have limited other exchanges (technology transfer, human rights and weapons sales) will have to be overcome before China can become a space partner ${ }^{26}$.

22 Another joint venture was initiated in 1996 to build satellite electronics and ground facilities between Xi'an Institute of Space Radio Technology and Canada's Com Dev Xi'an. In May 1990, Chinese and Russian industrial representatives signed an agreement for co-operation on ten projects. In 1994, China and Russia signed a protocol for space co-operation. In April 1996, the Russian President Boris Yeltsin signed a joint understanding on space co-operation with Chinese space officials that included training Chinese specialists at Russia's cosmonaut training facility at Star City. By the end of 1996 the Russian Space Agency was reported to be close to signing contracts with China concerning commercial spacecraft launches, although it is unclear what the outcome was. Similarly, details regarding a framework agreement between China and Kazakhstan in 1998 remain elusive. The assistance from Russia and the former Soviet Republics provides the greatest source of space co-operation for China, because Russia does not place significant restrictions on its co-operation.

China's co-operation with the United States on a governmental level in the area of satellite technology has been chequered. The first delegation of space officials from China to visit National Aeronautics Space Administration (NASA) was in December 1978. The priority areas the Chinese identified were the purchase of a domestic communications satellite system and access to NASA's earth resource sensing satellites $^{27}$. The Chinese announced its intent to market its satellite launches on the international market in $1985^{28}$. This forced the Chinese government to focus its attention on its relations with the United States. In fact, all commercial communication satellites are manufactured by US companies or include US components which have meant that export licences are required. 
Outer space weaponisation agreements ${ }^{29}$, which are in force. The important agreements are the Limited Test-Ban Treaty (1963), the Outer Space Treaty $(1967)^{30}$, the Convention on International Liability for Damage Caused by Space Objects (1972), the Environmental Modification Convention (ENMOD) (1977), and the Moon Agreement (1979). China is neither signatory nor party to the Moon Agreement and the Environmental Modification Convention, but is a member of the United Nations Committee on the Peaceful Uses of Outer Space (COPUOS) since 1981. Beijing has said it is not engaged in competition with the other space powers. But weaponisation of outer space many not be a dominant issue among the space-faring nations. There are technical issues which catch attention such as dual-use technology, the stormy remote sensing regime may have greater implications in space policy-making in the future.

China signed the 1967 Outer Space Treaty on January 27th 1967, ratified on July 24th 1970. China acceded to the 1967 Outer Space Treaty in December 30th 1983. The 1967 Outer Space Treaty is the most comprehensive of all the international agreements concerned with outer space, containing measures on both the peaceful uses of outer space and arms limitation in that environment. The Outer Space Treaty is a weaponsspecific treaty, which prohibits, inter alia, the placing or testing of nuclear weapons or any other kinds of weapons of mass destruction in outer space ${ }^{31}$. The Limited Test Ban Treaty and the Environmental Modification Convention are two activity-specific instruments that do not prohibit the placing or use of weapons in outer space but do cover certain effects, which the use of these devices could have on the outer space environment. This includes the testing of any nuclear weapons or any other nuclear explosion, as well as engagements in military or any other hostile use of environmental modification techniques in particular circumstances. Other constraints on military use of outer space, as mentioned earlier, include bilateral agreements undertaken between the United States and the former Soviet Union, the 1972 Anti-Ballistic Missile Treaty being the most important of such agreements to date.

There are problems and security concerns while addressing the potential military activities covered by the present international regime. The Moon Agreement, which contains some very important prohibitions of military use of outer space, has been signed or ratified by only thirteen states. As a result, the international regime on outer space is not as extensive as it may appear. The problem of treaty adherence implies that, among the major prohibitions related to weapons and other military use of outer space, only those inscribed in the Outer Space Treaty are in force for the majority of the international community. Prohibitions in weapons-specific agreements do not comprise all possible forms of military use technologies. Major efforts to improve the international regime directed to closing the gap regarding the placing into orbit of conventional or other weapons, which are not considered weapons of mass destruction. These efforts coupled with initiatives to establish a total ban on research, production, testing, storage, and the use of Earth or space-based systems designed to damage, destroy or interfere with the operations of objects in outer space. However, these initiatives are faced with major problems of political, military, practical and financial natures, which countries have for years failed to surmount.

The November 2000 White Paper of the People's Republic of China included national security as one of the purposes served by the space programme, and China's remote 
sensing, communications, and navigation satellites presumably satisfy both military and civilian objectives. Two Chinese satellites (ZY-2 and ZY-2B) are widely considered in the West to be for military reconnaissance ${ }^{32}$.

In its 2003 annual report on "Military Power of the People's Republic of China", the US Department of Defense asserts that the human spaceflight effort eventually could aid Chinese military space capabilities ${ }^{33}$. It also suggests that China may be developing a direct-ascent anti-satellite (ASAT) weapon, systems to jam US navigation satellite signals, and ground-based lasers to damage optical sensors on satellites. China's interest in missile defences is likely long-standing, and may currently include interest in developing NMD as well as defences against shorter-range missile systems. Zhang Houying, a space application specialist at the Chinese Academy of Sciences explained in February 2003 that Shenzhou spacecraft carry equipment for military surveillance. The Shenzhou $\mathrm{V}$ carries a camera capable of a ground resolution of 1.6 metres.

China's diplomacy on outer space issues in the United Nations

China views current international legal instruments inadequate to prevent an arms race in outer space. Consequently, China has proposed on numerous occasions the establishment of an Ad Hoc committee on the Prevention of an Arms Race in Outer Space (PAROS) at United Nations' Conference on Disarmament (UNCD). Beijing wants this committee to be "an open-ended and all-embracing mechanism within which all sides can freely express their own views" ${ }^{34}$.

The United States, however, has been resolute in its opposition to PAROS. The Bush administration will most likely continue to avoid any agreement that could curtail its plans to develop and deploy missile defence systems. In 2002 session of the UNCD, the Bush administration seemed unwilling to alter its stance, even if it meant continued stagnation on other issues such as a fissile material treaty. Officially, the United States has opposed the formation of an ad hoc committee, in part criticising the ambiguity of the proposed mandate. Conflict between the United States and China has made reaching consensus in the UNCD impossible. While China has been persistent in its efforts to keep the PAROS on table, the United States has been equally persistent in its efforts to block it. As a result, China has blocked further work on a treaty to control fissile material, which the United States believes to be a priority for the UNCD. This has lead to stalemate since 1997, preventing agreement on a Programme of Work and essentially stalling the work of the entire Conference.

31 China softened its demands, showing willingness to settle for less formal discussion, although with the continued understanding that the talks would be aimed at creating a binding agreement. The United States, however, found this compromise unacceptable since the assumption remained that the final product of these discussions would be in the form of a formal agreement ${ }^{35}$. In May 2002, the delegations of China and Russian Federation jointly presented a working paper to the UNCD, in the hope that all other delegations will carefully study, support and co-sponsor this paper. Both delegations again called for the establishment to an Ad Hoc Committee on PAROS at the UNCD, "so as to start substantive work on the negotiation of such a legal instrument" ${ }^{36}$. But in September 2002, the UNCD once again ended its session without reaching an agreement on a programme of work ${ }^{37}$.

Future programmes

The White Paper on "China's Space Activities" released on November 22nd 2000 outlines a strategy for the short-term (next decade) and a strategy for the long term 
(next two decades). One of the objectives of China's plan for manned flights and a space station is to further space-based military strategies. However, the exact military applications that the Chinese envisage are at best speculative at this stage.

Chinese scientists have predicted a Chinese mission to the moon by 2010 and are planning missions to Mars. "We will be able to embark on a maiden unmanned mission within two and a half years, said Ouyang Ziyuan, Chief Scientist of the lunar programme, if the government endorses the scheme now"38. Huang Chunping, chief of the Long March space rocket programme, has declared that "China has now solved most of the manned space technology problems, and has the capability within three to four years to step on the Moon. In fifteen years China will match the world's top level space technology"39. China also plans to build and orbit its own space station. Official authorization to start its development was granted in February 1999 and, since then, a test chamber has been built ${ }^{40}$. In March 2002, Zhang Qingwei, President of the China Aerospace Science and Technology Corporation (CASC), declared that China was preparing to finalise development of a new launch vehicle capable of carrying a twenty-ton space station into orbit, to be launched "at an appropriate time this century" ${ }^{41}$.

China's space programme, like its nuclear programme, expanded from military to civil uses. China built up its space launch capabilities on the foundations of is InterContinental Ballistic Missiles (ICBMS) and the technology to improve their performance from the United States. The manned space flight, therefore, must be seen in the context of integrated civil-military benefits. In China's short-term plan to 2010 integrated civilmilitary observation and remote sensing capabilities from space may receive priority. Establishing independent satellite navigation and positioning systems, so critical for military missions, and surveillance capabilities from space are part of that plan. The contribution of the Chinese space programme to the Chinese Inter-Continental Ballistic Missile (ICBM) programme is difficult to quantify. The Long March family of rockets includes 12 different types of launch vehicles that can deliver payloads into low-Earth orbit (LEO), geo-synchronous orbit (GEO), sun-synchronous orbit (SSO). While such capabilities are impressive, they do not necessarily translate into improved ICBM expertise.

China is thought to be active in research an anti-satellite (ASAT) and other satellite technologies but the true state of its research programme is unclear. Chinese satellite and space programmes are a nearly indiscernible mix of civilian and military components and research which takes place at joint military and commercial facilities. As China comes to rely on its own civil and military satellite systems, it will be faced with the same vulnerabilities now faced by the United States. It seems uncertain that developing this technology is of great interest to China and the government has apparently committed considerable resources to satellite and space programmes. China has been researching and developing ASAT technologies for several years but its degree of commitment to the production and launch of ASAT and satellite weapons is uncertain $^{42}$.

The short-term development targets (for the next decade) are briefly as follows: ${ }^{43}$

- To build up an Earth observation system for long-term stable operation. The meteorological satellites, resource satellites, oceanic satellites and disaster monitoring satellites can be developed into an Earth observation system for long-term stable operation to conduct stereoscopic observation and dynamic monitoring of the land, 
atmosphere, and oceanic environments of the country, the peripheral regions and even the whole globe;

To set up an independently operated satellite broadcasting and telecommunications system. Positive support will be given to the development of commercial broadcasting and telecommunications satellites such as geo-stationery telecom satellites and TV line broadcasting satellites with a long operating life, high reliability and large capacity, so as to form China's satellite telecom industry; monitoring and targeting military assets) as well as to anti-GPS (Global Positioning System) jamming technology. The European Space Agency (ESA) and European Union (EU) have jointly developed the Galileo satellite navigation programme, which will rival and perhaps outperform the GPS of the United States. Scheduled to be functional by 2008 , it is designed to provide users, ranging from aircraft and ships to surface transport vehicles and hikers and trekkers, with a navigational fix accurate to the meter. Although Galileo is designed specifically for civil purposes and is a real alternative to the de facto monopoly of the military in outer space. China has already invested heavily in this project.

50 An agreement has been initialled between the EU and China on its participation in the Galileo programme in Beijing in September 2003. Pertaining to the EU-China Galileo 
Project, Loyola de Palacio, European Commission Vice-President in charge of Transport and Energy, has explained that "The EU-China agreement on the Galileo Project will do more than secure a promising future for Galileo and European business interests: it opens the way for China's participation in the Galileo joint undertaking and a substantial financial stake-holding of some 200 million euros" ${ }^{45}$.

The US attitude towards China has to do with questions about the potential military applications of its manned space programme. But over the five decades of space flight it has been well established that reconnaissance satellites are far more effective than crewed missions when it comes to the military uses of space. In any case, it seems reasonable to assume that Chinese money spent on peaceful space endeavours-such as participation in the International Space Station project and perhaps in joint missions to the moon and Mars-is money not spent on the military uses of space ${ }^{46}$.

It is often argued that outer space technologies are not inherently harmful. This is an important assumption. The scale of China's military programme, the progress made in Chinese technology may be assessed through its commercial programmes. The commercial aspects of China's space launchers have been in the hands of the China Great Wall Industry Corporation since the end of the 1980s. China's space budget was estimated at US $\$ 1$ billion in $2001^{47}$. The United States have put tighter controls on the export of sensitive equipment, and banned American companies launching their satellites from China ${ }^{48}$. Outer space technologies have a number of intrinsic implications for international security, which seem to become ever more significant in light of two major factors: ${ }^{49}$ one is an increase in the levels of technology acquired by major outer-space competent states, and the other is the expanding access to such technologies by emerging outer space-competent states. Concomitantly, the role of outer space applications has evolved considerably throughout these decades, ultimately influencing the development of military doctrine and the various direct and indirect military uses of these technologies.

The series of satellites launched by China will have use in direct broadcasting, large capacity communications, meteorological and oceanographic observations, navigation and positioning, disaster mitigation, and seed husbandry. CASC offered five series of satellites which include retrievable satellites. Dongfanghong (East is Red) comsat, Fengyun (Wind and Cloud) metsats, Shijian (Practice) science exploration satellites, and Ziyuan (Resource) remote sensing satellites. The CASC is also responsible for building and launching Beidou (Northern Dipper) Navigation Test Satellites. Research and development would raise these satellites to a new level in the coming decades. In the area of large capacity comsats, CASC plans to accelerate research and development to increase capacity, efficiency, bandwidth and life expectancy of the satellites to reach international level ${ }^{50}$.

For the remote sensing satellites, successors will have higher resolution imagers in more spectral bands and a longer operating lifetime. China may use them to survey natural resources, monitor desertification and long-term crop growth and yield estimates, monitor disaster and pollution, project site selection and evaluation, city planning, surveying and cartography. In the area of microgravity science, CASC will use retrievable satellites to conduct experiments in space life science, space material and new technologies, and space environment ${ }^{51}$.

55 China has also made more then five-hundred microgravity experiments in aerospace biology on nine satellites and two spaceships ${ }^{52}$. It has new varieties and new seed 
resources of which the space breeding in agriculture, microorganism and medicinal fungus are leading the world. At present, many countries make efforts for developing small satellites that have helped reap huge economic benefits in mobile communication and natural resources exploration. Since China launched its first manmade satellite Dongfanghong I in 1970, the CAST has succeeded in launching various types of satellites, including nine small manmade satellites. The SJ-5 in 1999 has helped advance China to the world's front rank in the small satellites area. The CASC has taken an important measure in furthering the reform and adapting to the development of the market economy: the Aerospace Dongfanghong Satellite Co., Ltd, a hi-tech enterprise jointly funded by the CASC and the Chinese Academy of Space Technology, will help advancing industrialisation of production.

China's launch of first manned flight into space on October 2003 brought about the diplomacy of competition rather than co-operation in the space arena. In a sense, China is ahead of Europe and alongside the United States and Russia as the real space powers. China is also the first developing country to have achieved this. Moreover, China is also making new overtures to join research on the International Space Station (ISS). Without China's participation, the ISS will not be a true international programme. China's space programme clearly owes much to the Russian Federation. However, it is not clear that Chinese manned programme could not have succeeded without Russian assistance, albeit at a slower pace.

The primary aim of China's space activities is to meet the growing demands of economic construction, national security, science and technology development, social progress, to protect China's national interests and build up a comprehensive national strength. In a country like China, anything linked to the military will encourage more political support than something with no military application. China has an extensive and well-developed programme for the exploitation of space. This has so far focused almost exclusively on developing space capabilities for "national social-economic objectives". During the last two decades or more, China has joined bilateral, regional, multilateral and international space co-operation in different forms, such as commercial launching service, which have yielded extensive achievements. The issue of space debris is a big challenge to further expansion of space activities. The relevant departments of China pay great attention to the problem, and have carried out research on this issue with related countries since the beginning of the 1980s. In addition, China has participated in multilateral co-operative projects, such as the Committee on Earth Observation Satellites, World Weather Monitoring, UN Decade of Disaster Mitigation, and International Solar Terrestrial Physics.

The breadth of space technology development and its applications that China has set its vision on for the new millennium certainly evoke a great deal of curiosity and admiration. The successful Shenzhou V and VI missions have yielded the desired benefits in terms of domestic legitimacy and international prestige. In the era of globalisation and information and communication technologies (ICTs), the industrialisation and corporatisation of outer space are hub areas. China will have to develop more trained manpower in respect of computer technology especially software in the realm of outer space. The increased privatisation, public-private participation and space tourism may become the order of the day. While one might be tempted to say that how the programme evolves needs to be watched, history also bears evidence to 
the fact that the Chinese already possess the political will and technological skill to find their own way into deep space.

\section{NOTES}

1. See Yanping Chen, “China's Space Policy: A Historical Review”, Space Policy, Vol. 7, No. 2, May 1991, pp. 116-128; Brian Harvey, The Chinese Space Program: From Conception to Future Capabilities, Chichester, Praxis Publishing, 1998; Joan Johnson-Freese, The Chinese Space Program: A Mystery within a Maze, Malabar, FL, Krieger Publishing, 1998; Chen Zhiqiang, "Sun Jiadong Talking about China's Space Technology", Military World, Jan./ Feb. 1990, pp. 34-38. Also refer to "Swift Development of China's Missiles and Space Technology" An Interview with Mr. Liu Jiyan, Vice-minister of the Ministry of Aerospace Industry of China", CONMILIT, Vol. 3, No. 182, 1992, pp. 45-52; Gordon Pike, “Chinese Launch Services: A User's Guide, Space Policy, Vol. 7, No. 2, May 1991, pp. 103-115.

2. See Yanping Chen, op. cit., p. 122.

3. See Anne Gilks, “China's Space Policy”, Space Policy, August 1997, p. 216.

4. For a complete range of analysis on China's weaponisation efforts in outer space, see Matthew Mowthorpe, The Militarization and Weaponization of Space, Boulder, Lexington Books, 2004, pp. 83-108. See also, Michael B. Yahuda, China's Role in World Affairs, London, Croom Helm, 1978; Brian Harvey, The Chinese Space Program: From Conception to Manned Spaceflights, Chichester, Praxis Publishing, 1998.

5. See "China Steps Up ABM Technology Research" Kanwa News at <www.kanwa.com/ free/2001/ 06/eo613b\% 20 df31.htm>,

6. Yin Xingliang and Chen Dingchang, "Guidance and Control in Terminal Homing Phase of a Space Interceptor", Systems Engineering and Electronics 1995, Vol. 17, No. 6, 1995; Yin Xingliang, Chen Dingchang, and Kong Wei, "Tesoc Method Based on Estimated Value Theory for a Space Interceptor in Terminal Homing", Systems Engineering and Electronics, Vol. 17, No. 8, 1995.

7. Other major institutions dealing with space in China include the Ministry of Aeronautics and Astronautics Industry (MAAI), the Chinese Academy for Space Technology Research (CASTR) and the International Space Science Academy (ISSA).

8. This is known to be partly due to the political tension between China and the USSR in 1960 which affected co-operation in this field.

9. See Yang Chunfu, “China's Long March Series Carrier Rockets”, Military World, May 1989, p. 22. See also Wen-Rui Hu, Space Science in China, Amsterdam, Gordon and Breach, 1997.

10. For a detailed discussion, see Gordon Pike, op. cit., p. 107; Richard D. Risher Jr., "China's Missile Modernization and Space Warfare Plans", in K. Santhanam and Srikanth Kondapalli (eds.), Asian Security and China 2000-2010, New Delhi, Institute of Defense Studies and Analyses with Shipra Publications, 2004, pp. 170-176.

11. See He Changchui, "The Development of Remote Sensing in China", Space Policy, Vol. 5, No. 1, February 1989, pp. 65-75; Liu Ji-Yuan and Min Guirong, "The Progress of 
Astronautics in China", Space Policy, Vol. 3, No. 2, May 1987, pp. 141-47; Wu Guoxiang, “China's Space Communications Goals," Space Policy, Vol. 4, No. 3, February 1988, pp. 41-45. China is known to have launched several remote sensing satellites for military photographic intelligence purposes. See the various reports in the Stockholm International Peace Research Institute (SIPRI) Yearbook series, under "Military Use of Space”. See also Xing Shizhong, "China Threat Theory May be Forgotten", Qiushi, February 3rd 1996, in FBIS-CHI, February 1st, 1996, and Gao Jiguan, "China Holds High Banner of Peace", Jiefangjun Bao (Liberation Army Daily), June 27th 1996, in FBIS-CHI, June 27th 1996.

12. Asiasat [Asia Satellite], Arabsat [Arab Satellite], Freja [Swedish Satellite], Australian Satellite [Aussat].

13. "Swift Development of China's Missiles and Space Technology: An interview with Mr. Liu Jiyan, Vice-Minister of the Ministry of Aerospace Industry of China", op. cit., p. 53. See also Chen Zhiqiang, "Sun Jiadong Talking about China's Space Technology", Military World, January/February 1990, pp. 34-38. See also, Yanping Chen, op. cit., p. 126. 14. "PRC Space Official Says - China to Launch Next Shenzhou in 1-2 years", Beijing Xinhua in English, October 16th 2003, via Foreign Broadcasting Information Service (FBIS).

15. Joan Johnson-Freese, September 29th 2003 presentation to Center for Strategic and International Studies. Available at http://www.csis.org. See also Joan Johnson-Freese, The Chinese Space Program: Mystery within a Maze, Florida, Kreiger Publishing Co., 1998. 16. See William S. Murray III and Robert Antonellis, “China's Space program: The Dragon Eyes the Moon (and US), Orbis, Vol. 47, No. 4, Fall 2003, pp. 645-652.

17. The term "taikonaut" for Chinese astronaut comes from "taikongren" (WWW, spaceman).

18. See News from China, New Delhi, Vol. XV, No. 20, November 23rd 2003, pp. 15-16. See also Iton Yi, "Shenzhou 5 Launcher Ready for Transfer to Jiuquan Launch Site", Space Daily.com, August 11th 2003.

"Russia-China Conference on Disarmament (CD) Working Paper on New Space Treaty"; Disarmament Documentation, The Acronym Institute website, June 27th 2002, http:// www.acronym.org.uk/docs.

19. For details, See Li Li, “Up Goes Shenzhou, Again”, Beijing Review Vol. 48, No. 42, October 20, 2005, pp. 20-21.

20. The ISS is a co-operative venture among European Space Agency (ESA-eleven space agency member states), US, Russia, Canada and Japan for the joint development, operation and utilisation of a permanently inhabited space station in low-Earth orbit. For a detailed discussion, see Anna Maria Balsan and Aude de Clercq, "The Community Patent and Space Related Inventions", Journal of Space Law, Vol. 30, No. 1, 2004, pp. 1-11. 21. The Information Office of the State Council issued, on December 9th 2002, a white paper titled "China's National Defense in 2002", the fourth one of its kind released by the Chinese Government since 1995. For the complete text of the white paper see http://www.china.org.cn/fa-book/311/index.htm.

22. For a comprehensive analysis on this see, United Nations Institute for Disarmament Research (UNIDR), Outer Space and Global Security, Geneva, UNIDIR, 2003, pp. 4-10. 23. See the White Paper on “China's Space Activities" published on November 22nd 2000 by the Information Office of the State Council, Beijing Xinhua in English, via Foreign Broadcast Information Service (FBIS). November 22nd 2000, available at http:// chineseculture.about.com/library/china/whitepaper/bl_space2000.htm. 
24. Ibid.

25. For a detailed discussion on this, see Jason Sherman, "China Looks Askance at Space War Game", Defense News, February 28th 2001, p. 3; "China's National Defense", Information Office of the State Council of the People's Republic of China, July 27th 1998; Li Jijun, "Zhongguo junshi sixiang chuantong yu fangyu zhanlue" (Chinese traditional military thinking and defence strategy), Zhongguo junshi kexue (China Military Science), No. 4, Winter 1997, p. 62.

26. For details, see Craig Covault, "China Seeks ISS Role, Accelerates Space Program", Aviation Week and Space Technology, November 12th 2001, pp. 52-57.

27. See Stephen M. Shaffer and Lis Robock Shatter, The Politics of International Cooperation: A Comparison of U.S. Experience in Space and in Security, Vol. 17, Book 4, University of Denver, Colorado, December 1980, p. 26.

28. For a comprehensive analysis on this aspect, see Lin Dengrui, "China's Space Industry Forging Ahead", China Today, Vol. 45, No. 9, December 1996, p. 41.

29. For a complete text and details of space treaties, see the Office for Outer Space Affairs (OOSA), United Nations Office of Vienna. See also, Kart-Heinz Bockstiegel and Marietta Benko (eds.), Space Law: Basic Legal Documents, Dordrecht, Martinus Nijhoff, 1990.

30. 1963: Treaty Banning Nuclear Weapon Tests in the Atmosphere, in Outer Space and Under Water. 1967: Treaty on Principles Governing the Activities of States in the Exploration and Use of Outer Space, including the Moon and Other Celestial Bodies. 31. The Moon Agreement reiterates some of the obligations contained in the Outer Space Treaty, but also reflects the need to define and further develop certain provisions concerning the Moon and other celestial bodies, such as the threat or use of force and military specific activities. For a legal discussion of the Treaty, see Carl Q. Christol, The Modern International Law of Outer Space, 1982; for Soviet sources, see Guennady Zhukov and Yuri Kolosov, International Space Law, xiii, 1984; Du Shuhua, “The Outer Space and the Moon Treaties", Verification of Current Disarmament and Arms Limitation Agreements: Ways, Means and Practices, New York, UNIDIR, United Nations Publications, 1991.

32. For general information on these aspects, see the CASC Internet site.

33. See United States Department of Defense, available at http://www.defenselink.mil/ pubs/20030730chinaex.pdf. This site also discusses China's efforts to develop new space launch vehicles, "counterspace" systems, and to send humans into space.

34. See China Working Paper entitled “China's Position on and Suggestions for Ways to Address the Issue of Prevention of an Arms Race in Outer Space at the Conference on Disarmament", Conference on Disarmament (UNCD), CD/1606, February 9th 2000.

35. For a detailed and in-depth analysis of these aspect, see Wade Boese, "CD Inches Closer to Starting Negotiations", Arms Control Today, July/August 2002.

36. Press release by the delegation of China to the UNCD, May 29th 2002, available at http://www.china-un.ch/eng 130623. html. See also, "Russian-China CD Working Paper on New Space Treaty", Disarmament Documentation, The Acronym Institute website, June 27th 2002, httm://www.acronym. org.uk.

37. See UN Press Release, "Conference on Disarmament Adopts Annual Report, Concludes 2002 Session", September 9th 2002, http://www.un.org/ News/Press/docs/2002/dcf418.doc.htm. See also the Center for Nonproliferation Studies at the Monterey Institute of International Studies 
(MIIS) website at http://cns.miis.edu and Nuclear Threat Initiative at http: www.nti.org.

38. See "China could target moon by 2005", MSNBC, March 3rd 2003; Leonard David, “China's Space Program Driven by Military Ambitions”, space.com. March 13th 2002. [accessed on February 12th 2004].

39. See Wei Long, "China Hopes Manned Space Flight Will Open Road to Moon", Space Daily, May 21st 2002.

40. "Beijing Environment, Science and Technology Update”, U.S. Embassy-Beijing, September 21st 2001.

41. "China Plans Heavy Lifter to Launch Space Station and More", Space Daily, March 14 th 2002.

42. In the past thirty years China has launched over fifty indigenous satellites of ten types and more than twenty foreign satellites, "Achievements of Defense Conversion in China Aerospace Industry", Aerospace China, Vol. 2, No. 2, Summer 2001. See also John Pike, "The Paradox of Space Weapons", SIPRI Yearbook 2003-Armaments, Disarmament and International Security, Oxford, Oxford University Press, 2003, pp. 433-434.

43. White Paper on “China's Space Activities”, November 22nd 2000, op. cit.

44. Ibid.

45. See European Union, http://europa.eu.int/rapid/pressReleasesAction.do? reference $=I P / 03 / 1461 \&$ format $=$ HTML\&aged $=1 \&$ language $=$ FR \&guiLanguage $=e n$.

46. Ibid.

47. For a detailed discussion, see Laurence Nardon, “The World's Space Systems", in Kerstin Vignard (ed.), Making Space for Security?, Disarmament Forum, Geneva, United Nations Institute for Disarmament Research, 2003, pp. 33-40.

48. Ibid.

49. "Access to Outer Space Technologies: Implications for International Security, United Nations Institute for Disarmament Research (UNIDIR)", Research Papers, New York, 1992, p. XV. See also Aaron Karp, "Ballistic Missile Proliferation", World Armaments and Disarmament, SIPRI Yearbook 1991, London, Oxford University Press, 1991, p. 337. For a future implications of space security in this respect, see Daniel S. Papp and John R. McIntyre, International Space Policy: Legal, Economic, and Strategic Options for the Twentieth Century and Beyond, New York, Quorum Books, 1987.

50. See Wei Long, "Ambitions Space Effort Challenges China in Next Five Years", at http:/www.spacedaily.com/news/china-01W1.html accessed on January 3rd 2004.

51. Ibid.

52. See http://english.people.com.in/200109/29/eng20010929 81374.html accessed on January 10th 2004.

\section{RÉSUMÉS}

This article looks at China's outer space programme and its implications in terms of its military and non-military applications. Being a huge country and a permanent member of the United Nations Security Council, China's launch of the first manned space flight in October 2003 
constitutes a landmark event. High-level technological capability, such as in space exploration, add to a country's power and bargaining capacity at international level. This article thus also considers China's quest for position vis-à-vis other space-faring nations. 